\title{
Stage IIIB Merkel Cell Carcinoma AJCC v7
}

National Cancer Institute

\section{Source}

National Cancer Institute. Stage IIIB Merkel Cell Carcinoma A/CC v7. NCI Thesaurus.

Code C85899.

Stage IIIB includes: Any T, N1b/N2, M0. N1b: Macrometastasis in regional lymph nodes.

N2: In transit metastasis. M0: No distant metastasis. (AJCC 7th Ed.) 